\title{
Enhancing Remazol Yellow FG Decolorination by Adsorption and Photoelectrocatalytic Degradation
}

\author{
Sayekti Wahyuningsih $^{1}{ }^{*}$, Puji Estiningsih ${ }^{1}$, Velina Anjani ${ }^{1}$, Liya N.M.Z. Saputri ${ }^{1}$, \\ Candra Purnawan ${ }^{2}$, Edi Pramono ${ }^{1}$ \\ ${ }^{1}$ Inorganic Materials research Group, Faculty of Mathematics and Natural Sciences, \\ Universitas Sebelas Maret, Surakarta, Indonesia \\ ${ }^{2}$ Analytical and Environmental Research Group, Faculty of Mathematics and Natural Sciences, \\ Universitas Sebelas Maret, Surakarta, Indonesia \\ *email: sayekti@mipa.uns.ac.id
}

Received February 11, 2017; Accepted August 09, 2017; Available online November 30, 2017

\begin{abstract}
The combination of adsorption and photoelectrocatalytic degradation system for Remazol Yellow FG decolorization has been studied. The adsorption of Remazol Yellow FG was carried out using alumina and silica, which was activated using $\mathrm{H}_{2} \mathrm{SO}_{4} 1 \mathrm{M}$ and $\mathrm{NaOH} 1 \mathrm{M}$. The adsorption results at optimum $\mathrm{pH}$ were then used for photoelectrocatalytic process. Photoelectrocatalytic degradation cell was built by electrode $\mathrm{Ti} / \mathrm{TiO}_{2}$ as a cathode and $\mathrm{Ti} / \mathrm{TiO}_{2}-\mathrm{PbO}$ as an anode. Material characterizations were performed by UV-Vis Spectrophotometers, X-Ray Diffraction (XRD), and Fourier Transform Infra-Red (FTIR). Activation of the adsorbent can increase Remazol Yellow FG adsorption on alumina base and silica acid that were reached $99.500 \%$ and $81.631 \%$, respectively. The optimum condition of Remazol Yellow FG 6 adsorption by alumina acid was at $\mathrm{pH} 3$, alumina base was at $\mathrm{pH} 4$ and $\mathrm{pH} 5$, and silica base was at $\mathrm{pH} 6$ and $\mathrm{pH} 10$. Degradation of Remazol Yellow FG using $\mathrm{TiO}_{2}-\mathrm{PbO}$ electrode was $72.756 \%$ at potential cells of 7.5 Volts for 10 minutes. The combination of adsorption and photoelectrocatalytic degradation can decrease the concentration of Remazol Yellow FG achieved 99.705\%.
\end{abstract}

Keywords: Adsorption, photocatalytic, Titania, dye, $\mathrm{pH}$

\section{INTRODUCTION}

The textile industry was known to be one source of water pollution due to textile production that passes through several stages of the process such as dyeing; leaching, measurement, printing, and improvement that have potentially produce waste. The negative impact of textile production mainly comes from the dyeing process. The chemical structure with the aromatic ring of dye causes highly toxic waste, carcinogenic, mutagenic, allergies and dermatological diseases (Gao et al., 2013). Various waste treatments such as filtration, coagulation, sedimentation, ion exchange and adsorption have been carried out. The adsorption is one of wastewater treatment that most effective and widely used in the waste treatment process for highefficiency, easy in operation, biodegradability, and low cost (Gupta et al., 2013; Yola et al., 2014)

Alumina and silica have high efficiency due to the large of surface area, high porosity, good mechanical properties and good resistivity to thermal degradation (Mahmoud et al., 2010; Malakootian et al., 2015). The surface area of alumina and silica were known
$155 \mathrm{~m}^{2} / \mathrm{g}$ and $500 \mathrm{~m}^{2} / \mathrm{g}$, respectively (Mahmoud, 2005; Gawade et al., 2005). The active surface silica contains silanol ( $\mathrm{Si}-\mathrm{OH})$ that has an important function in the adsorption process. The behavior of alumina adsorption was caused by hydroxyl acids and bases on its surface. Based on this reason, the silica and alumina can be used as an adsorbent in the adsorption of Remazol Yellow FG. The adsorption process may only a physical interaction and sometimes have effective for waste dyes treatment. Therefore, it needs the photoelectrocatalytic waste treatment that capable to degrade organic waste to minerals compound.

The semiconductor of $\mathrm{TiO}_{2}$ has been widely studied and used as a photocatalyst because of the high photocatalytic activity, low cost, and stable (Grimes et al., 2011; Ni et al., 2011). However, $\mathrm{TiO}_{2}$ has a wide energy gap $(3.2 \mathrm{eV} ; \lambda \mathrm{g}=388 \mathrm{~nm})$ that only able to absorb in the UV region whereas only $10 \%$ of the sunlight. Modification $\mathrm{TiO}_{2}$ was able to increase light absorption in the visible region. It has become one of the topics of research of photocatalyst area (Henderson et al., 2011; Rehman et al., 2012; Fujishima et al., 2008). 
$\mathrm{PbO}$ has a low band gap that can be used as a visible light oxide semiconductor. Computational studies approaches have shown that the modified $\mathrm{TiO}_{2}-\mathrm{PbO}$ produce valence band of $\mathrm{TiO}_{2}$ has shifted into the visible region (Iwaszuk et al., 2008). Therefore, this composite allows for the migration of the charge and charge carrier separation photogenerated (Leelavathi et al., 2013). The use of $\mathrm{TiO}_{2}-\mathrm{PbO}$ as photoanoda which can absorb the visible region will enhance the ability photoanode in the degradation of organic compounds.

In this report, we have studied the decolorization of Remazol Yellow FG by adsorption and photoelectrocatalytic degradation system. First, the remazol yellow was adsorbed into alumina and silica adsorbents. Then, we also do the decolorization using the system.

\section{EXPERIMENTAL SECTION}

The material consists of Ti plate $(3 \mathrm{~cm} \mathrm{x} 10$ $\mathrm{cm}$ ) of Baoji Titanium Qixin Co. Ltd, alumina, silica, Remazol Yellow FG, titanium tetraisopropoxide (TTIP), ethanol, acetic acid, lead nitrate, hydrochloric acid and sodium hydroxide. The materials were used without further pre-treatment.

The activation of alumina $(50 \mathrm{~g})$ and silica $(50 \mathrm{~g})$ were carried out by adding into 1 $\mathrm{M} \mathrm{H}_{2} \mathrm{SO}_{4}(250 \mathrm{~mL})$ and $1 \mathrm{M} \mathrm{NaOH}(250 \mathrm{~mL})$, respectively, then stirred for 1 hour. The result was washed using distilled water to neutral conditions.

An optimum condition of adsorbent properties was carried out by adsorption of 10 ppm Remazol Yellow FG on untreated silica and alumina, and acid and base activated. Then they were stirred at $120 \mathrm{rpm}$ for 60 minutes. The residual of Remazol Yellow FG was analyzed by UV-Vis spectrophotometer. Remazol Yellow FG at various $\mathrm{pH}(\mathrm{pH} \mathrm{3,} \mathrm{4,} \mathrm{5,}$ $6,7,8,9,10$, and 11) have been carried out by adsorption using activated silica and activated alumina. Each sample was stirred for 60 minutes. The residuals were also analyzed by $\mathrm{UV}-\mathrm{V}$ is spectrophotometer.

Preparation of $\mathrm{Ti} / \mathrm{TiO}_{2}$ electrode refers to the Wahyuningsih methods (Wahyuningsih et al., 2007a, 2014b). Titanium isopropoxide solution (TTIP) was added acetic acid at a temperature of $14{ }^{\circ} \mathrm{C}$ then it was stirred and heated to a temperature of $90{ }^{\circ} \mathrm{C}$. The gel obtained was heated at a temperature of $150{ }^{\circ} \mathrm{C}$ for \pm 24 hours and then annealed to $400{ }^{\circ} \mathrm{C}$ at $10{ }^{\circ} \mathrm{C} / \mathrm{min}$. Preparation of $\mathrm{Ti} / \mathrm{TiO}_{2}$ electrode was done by mixing $\mathrm{TiO}_{2}$ powder into ethanol then it was stirred and sonicated for 60 minutes. The $\mathrm{TiO}_{2}$ suspension then was sprayed to titanium plate and heated at a temperature of $200{ }^{\circ} \mathrm{C}$ for 15 minutes. The electrodes characterization was performed by XRD.

The same treatment was done for the preparation of $\mathrm{TiO}_{2}-\mathrm{PbO}$ composite, except for the addition of $\mathrm{PbNO}_{3}(3.31 \mathrm{~g})$. Preparation of $\mathrm{Ti} / \mathrm{TiO}_{2}-\mathrm{PbO}$ electrode was done by mixing $\mathrm{TiO}_{2}-\mathrm{PbO}$ composite $(12.5 \mathrm{~g})$ into ethanol (50 $\mathrm{mL}$ ) then it was stirred and sonicated for 60 minutes. The $\mathrm{TiO}_{2}-\mathrm{PbO}$ solution then was sprayed to titanium plate and heated at a temperature of $200{ }^{\circ} \mathrm{C}$ for 15 minutes. The electrodes characterization was also performed by XRD.

The photoelectrocatalytic process of Remazol Yellow FG (10 ppm) has been carried out at the optimum $\mathrm{pH}$ condition of adsorption process. $\mathrm{Ti} / \mathrm{TiO}_{2}$ electrode was used as a cathode, while $\mathrm{Ti} / \mathrm{TiO}_{2}-\mathrm{PbO}$ electrode was used as an anode. The process was prepared using a positive potential bias of 7.5 volts for 10 minutes by batch system. Remazol Yellow FG removal in the photoelectrocatalytic process was analyzed using a UV-Vis spectrophotometer.

\section{RESULTS AND DISCUSSION}

Adsorbent activation indicates there is an $\mathrm{OH}$ group stretching vibration of untreated alumina, and acid and base activated at $3462.37 \mathrm{~cm}^{-1}, 3461.41 \mathrm{~cm}^{-1}$, and $3459.48 \mathrm{~cm}^{-1}$, respectively. While at $1630.88 \mathrm{~cm}^{-1}, 1634.74$ $\mathrm{cm}^{-1}$, and $1636.67 \mathrm{~cm}^{-1}$ show the bending vibrations of $\mathrm{OH}$ groups. Absorption at 775.42 $\mathrm{cm}^{-1}, 731.05 \mathrm{~cm}^{-1}$, and $732.98 \mathrm{~cm}^{-1}$ was observed of the untreated alumina, and acid and base activated, respectively due to the stretching vibration Al-O group.

Figure 1 shows the $\% \Delta \mathrm{T}$ represented of the amount of $\mathrm{OH}$ active sites on the untreated alumina surface, and acid and base activated alumina. Those differences indicate that a change in the amount of $\mathrm{OH}$ active sites on the untreated activated alumina surface as well as activated alumina surface which can affect the absorption ability of the adsorbents. 


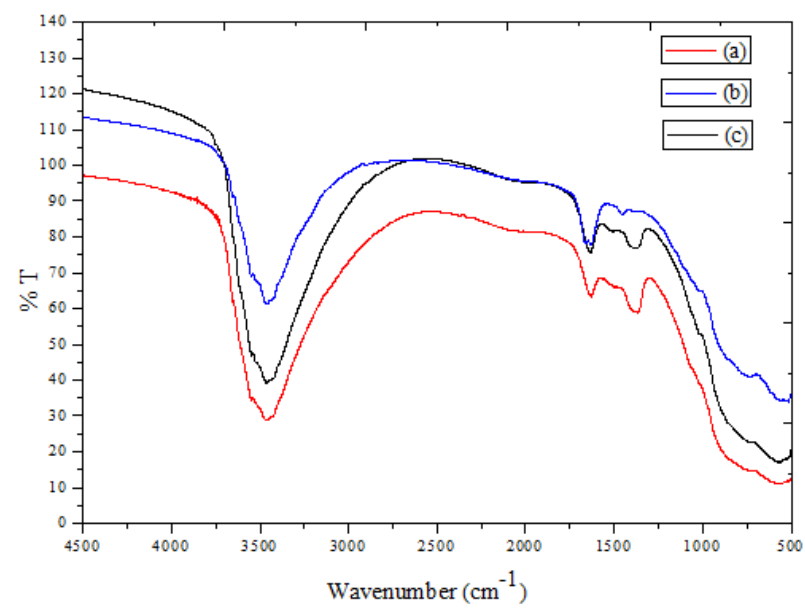

Figure 1. FT-IR spectras of the alumina (a) untreated ; (b) acid activation; (c) base activation

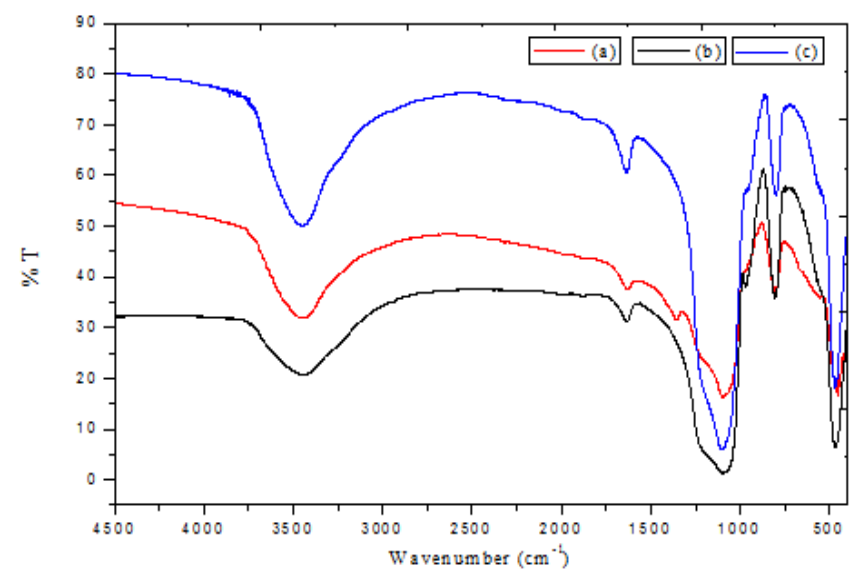

Figure 2. FT-IR spectras of the silica (a) untreated; (b) acid activation; (c) base activation

Whereas on the untreated silica and acid and base activated silica (Figure 2) shows the $\mathrm{OH}$ stretching vibration of silanol at 3444.05 $\mathrm{cm}^{-1}, 3462.37 \mathrm{~cm}^{-1}$, and $34401.19 \mathrm{~cm}^{-1}$. While at $1632.81 \mathrm{~cm}^{-1}$ was base activated silica and at $1631.85 \mathrm{~cm}^{-1}$ was untreated silica as well as acid activated by bending vibration $-\mathrm{OH}$ of silanol. Absorption at $1095.61 \mathrm{~cm}^{-1}, 1083.08$ $\mathrm{cm}^{-1}$, and $1101.40 \mathrm{~cm}^{-1}$ are asymmetric stretching vibration $-\mathrm{Si}-\mathrm{O}$ of $-\mathrm{Si}-\mathrm{O}-\mathrm{Si}-$ (siloxane group). Bending vibrations of Si-OSi was shown at $560.18 \mathrm{~cm}^{-1}, 468,72 \mathrm{~cm}^{-1}$, and $472.58 \mathrm{~cm}^{-1}$. The differences of $\mathrm{OH}$ active sites on the untreated silica surface as well as activated silica surface may also affect the ability of adsorption.

In untreated, acid and base activated alumina, adsorption Remazol Yellow FG obtained the decolorizations about $75.51 \%$, $99.50 \%$ and $78.05 \%$, respectively (Figure 3a). Remazol Yellow FG adsorption with acid activated alumina is highest. Alumina has been known a high affinity for anionic species on acid activation.
Remazol Yellow FG adsorption with untreated, acid and base activated silica, adsorption Remazol Yellow FG obtained the decolorization $73.93 \%, 77.12 \%$, and $81.63 \%$, respectively (Figure 3b). Remazol Yellow FG adsorption using base activated silica is highest due to the effective interaction of -Si-O- and $\mathrm{H}_{2} \mathrm{O}$ formed positive site of lewis acid silica that will interact with anionic sites of Remazol Yellow FG.

Furthermore, the $\mathrm{pH}$ effect was also investigated. Adsorption study with base activated alumina was optimum at $\mathrm{pH} 10$ about $77.87 \%$ and at $\mathrm{pH} 4$ about $76.87 \%$ (Figure 4a). Adsorption with base activated silica optimum at $\mathrm{pH} 10$ about $82.62 \%$ and at $\mathrm{pH} 6$ about $81.96 \%$ (Figure 4b). Under alkaline conditions, it may structural transformation of Remazol Yellow FG form a vinyl sulfone group. Under acidic conditions it also probably generates structural transformation forming vinyl sulfone group because of the protonation by $\mathrm{H}^{+}$. The vinyl sulfonic group was further interacting with adsorbent. 


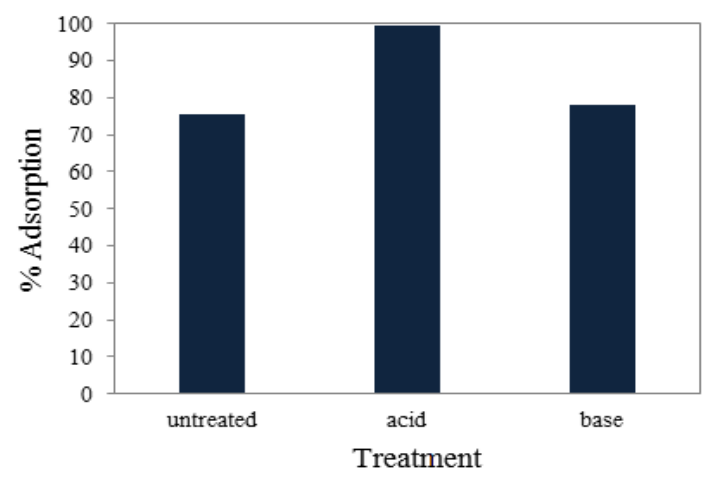

(a)

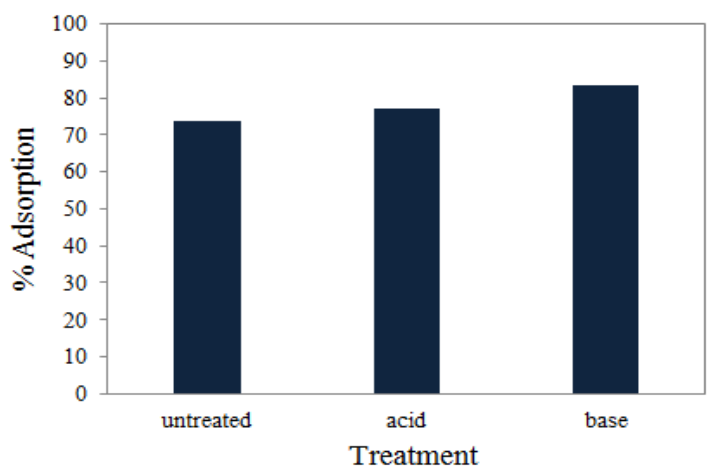

(b)

Figure 3. The effect of acid and base activation toward Remazol Yellow FG adsorption at pH 6,8 (a) alumina; and (b) silica

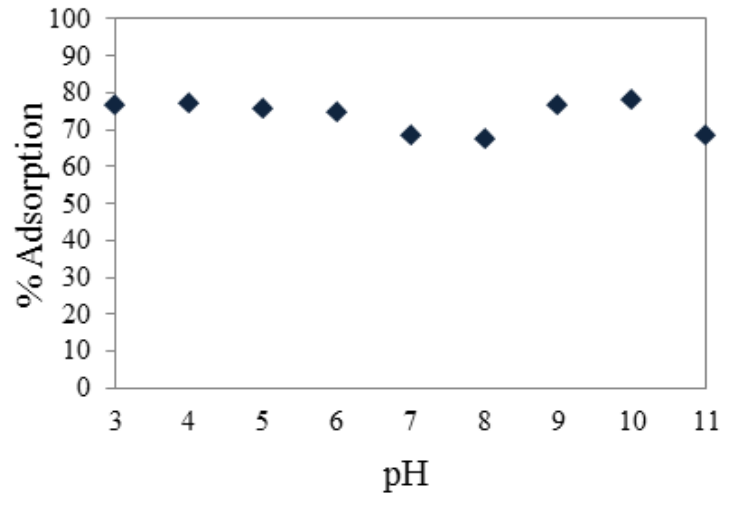

(a)

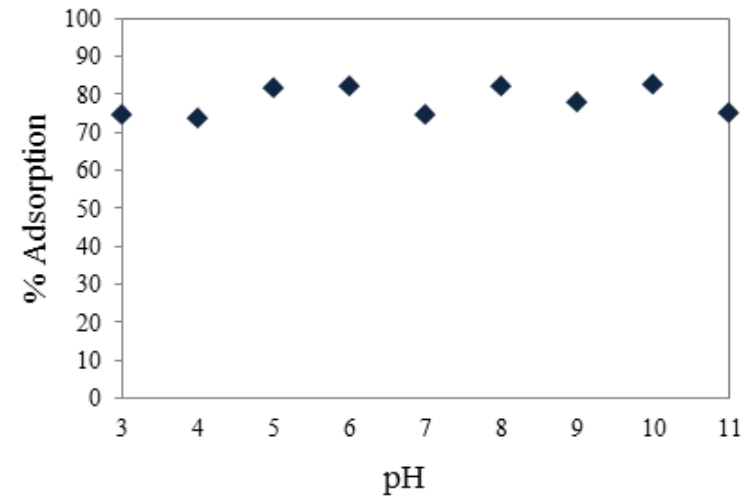

(b)

Figure 4. The effect of $\mathrm{pH}$ toward Remazol Yellow FG adsorption using (a) base alumina; and (b) base silica

Adsorption Remazol Yellow FG with acid activated alumina was optimum at $\mathrm{pH} 3$ about $98.90 \%$ (Figure 5a). Remazol Yellow FG structure is a cationic acceptor, which will react with $\mathrm{H}^{+}$ions from the alumina, because of the cations exchange between $\mathrm{H}^{+}$and $\mathrm{Na}^{+}$ from Remazol Yellow FG. In the acid activated silica, adsorption Remazol Yellow FG occurs at pH 7 about $78.72 \%$ (Figure 5b). This due to alumina is more acidic Brønsted, compared with silica acid so that it produces a high adsorption.

The use of $\mathrm{Ti} / \mathrm{TiO}_{2}-\mathrm{PbO}$ composites as electrodes is proven to degrade Remazol Yellow FG. The excitation of electrons from the valence band to the conduction band will leave the hole in the valence band. The electrons in the resulting $\mathrm{TiO}_{2}$ conduction band may trigger the reaction with $\mathrm{O}_{2}$ resulting in a superoxide anion radical $\left(\mathrm{O} 2^{\circ}\right)$. The holes form will react with $\mathrm{H}_{2} \mathrm{O}$ to produce a hydroxyl radical $\left(\mathrm{OH}^{*}\right)$. Superoxide anion radicals $\left(\mathrm{O}_{2}^{--}\right)$and hydroxyl radicals $\left(\mathrm{OH}^{*}\right)$ will degrade Remazol Yellow FG dye through redox reactions.

The electrons in the conduction band can return to the valence band. The addition of oxide is capable of suppressing electron-hole recombination by electron trapping on metal sites where electrons will migrate toward metal and trapped in metal. This results in the hole freely diffusing onto the semiconductor surface and effectively enhances the photocatalytic effectiveness in degrading the Remazol Yellow FG dye.

Positive potential through photoanode will attract electrons to the cathode then minimize electron-hole pair recombination and accelerate the oxidation process of organic compounds (EPA, 2003). Also, the addition of positive potentials will cause excited electrons split and holes to be accelerated (Hu et al., 2003). 


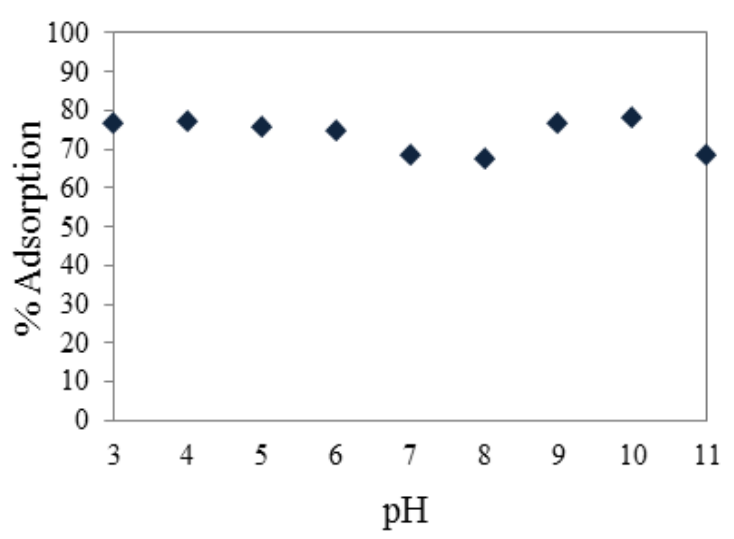

(a)

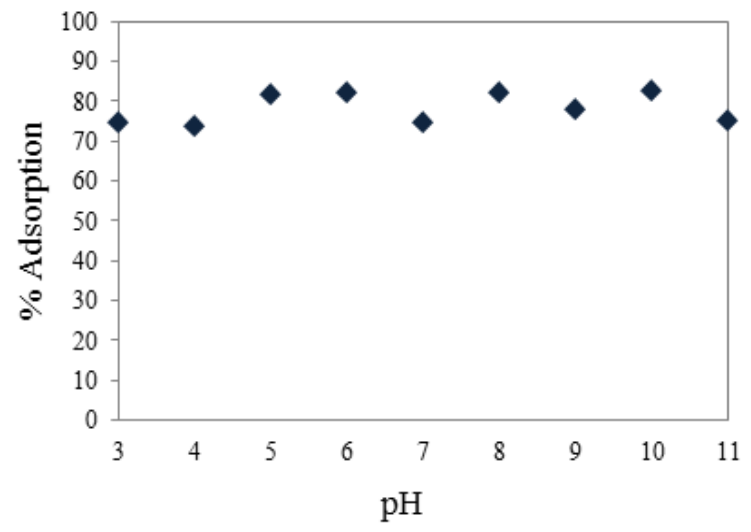

(b)

Figure 5. The effect of pH toward Remazol Yellow FG adsorption using (a) acid alumina; and (b) acid silica

Possible reactions that can occur in electrodegradation cells are as follows:

$$
\begin{aligned}
& \mathrm{R} m z \mathrm{Y} \rightleftharpoons \mathrm{R} m z \mathrm{Y}^{+}+\mathrm{e}^{-} \\
& 2 \mathrm{H}_{2} \mathrm{O}+2 \mathrm{e}^{-} \rightleftharpoons 2 \mathrm{OH}^{-}+\mathrm{H}_{2} \\
& \text { hole }^{+}+\mathrm{OH}^{-} \longrightarrow \mathrm{OH}^{\circ} \\
& \mathrm{OH}^{\cdot}+\mathrm{Rmz} \mathrm{Y} \longrightarrow \operatorname{produk}\left(\mathrm{CO}_{2}+\mathrm{H}_{2} \mathrm{O}\right) \\
& \mathrm{R} m z \mathrm{Y}+\mathrm{e}^{-} \rightleftharpoons \mathrm{R} m z \mathrm{Y}^{-} \\
& 2 \mathrm{H}_{2} \mathrm{O} \rightleftharpoons \mathrm{O}_{2}+4 \mathrm{H}^{+}+4 \mathrm{e}^{-}
\end{aligned}
$$

Photoelectrocatalytic degradation of Remazol Yellow $\mathrm{FG}$ using $\mathrm{Ti} / \mathrm{TiO}_{2}-\mathrm{PbO}$ electrode as anode and $\mathrm{Ti} / \mathrm{TiO}_{2}$ electrode as cathode can degrade Remazol Yellow FG. The preparation procedure of electrode materials will be published in a separate report. Degradation using photoanode $\mathrm{Ti} / \mathrm{TiO}_{2}-\mathrm{PbO}$ on Remazol Yellow FG reached $62.06 \%$.

The optimum degradation occurs in the initial solution $\mathrm{pH} 3$ Remazol Yellow FG, about $72.756 \%$. Figure $\mathbf{6}$ shows that differences in the $\mathrm{pH}$ of the initial solution Remazol Yellow FG influenced degradation. This is due, acid solution Remazol Yellow FG already protonated form a positive charge. Thus affinity to the reaction of hydroxyl radicals $\left(\mathrm{OH}^{\circ}\right)$ and superoxide anion radicals $\left(\mathrm{O}^{\circ}{ }^{-}\right)$is higher. Addition of $\mathrm{HCl}$ also affects the degradation Remazol Yellow FG. The $\mathrm{Cl}$ can be oxidized to generate the $\mathrm{ClO}^{3-}$ species. These species turn out to be powerful oxidizing agents, which together with the hydroxyl radicals can degrade the dye thus at pH 3 the degradation Remazol Yellow FG becomes higher (Cerventes et al., 2012).

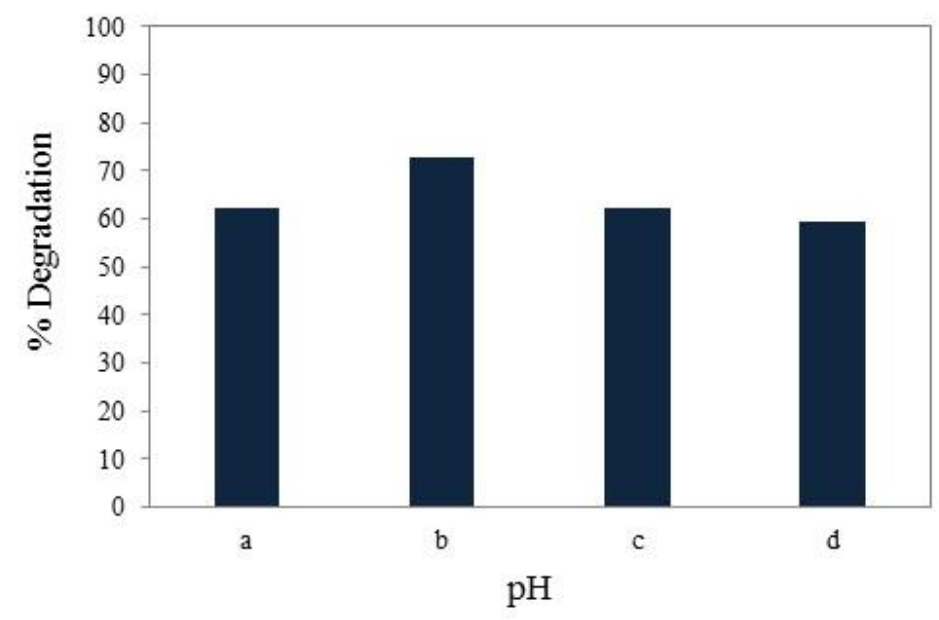

Figure 6. Degradation of Remazol Yellow FG after photoelectrocatalytic degradation process with applied bias potential $7.5 \mathrm{~V}$ for $10 \mathrm{~min}$ at various $\mathrm{pH}$ (a) RY neutral (at pH 6,8); (b) RY at pH 3; (c) RY at pH 7; and (d) RY at pH 10 


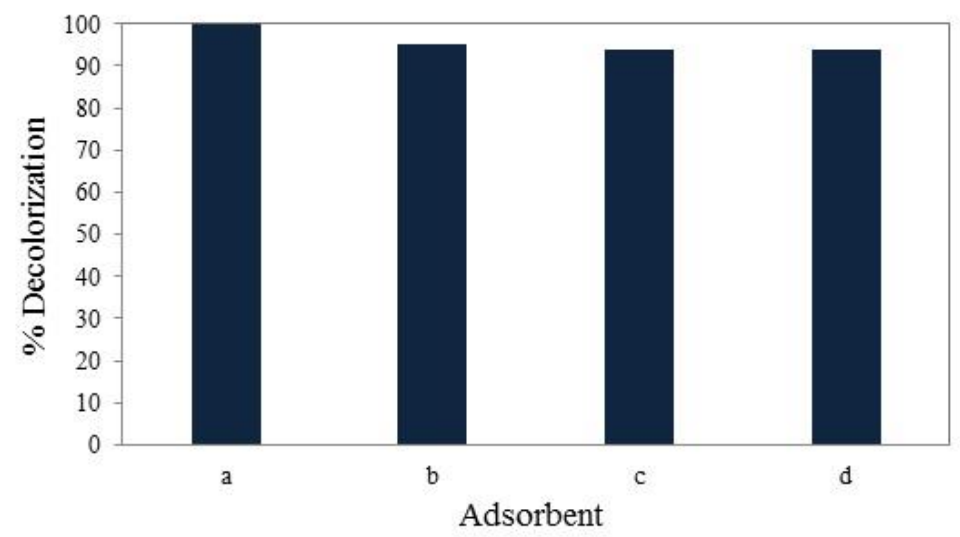

Figure 7. Decolorization of Remazol Yellow $F G$ with adsorption and photoelectrocatalytic degradation process using (a) acid alumina; (b) base alumina; (c) acid silica; and (d) base silica. Photoelectrocatalytic degradation process was conducted at potential cells of $7.5 \mathrm{~V}$ for 10 minutes.

The decolorization of Remazol Yellow FG using a combination of adsorption and photoelectrodegradation, about $99.70 \%$ and $95.30 \%$ for acid and base activated alumina, respectively. While, for acid and base activated silica, about $94.01 \%$, and $94.02 \%$, respectively (Figure 7).

Hydrated alumina tends electronwithdrawing than silica, due to Lewis acid sites (Kannan et al., 2008). Activated alumina is more Brønsted acid. Thus the interaction between the active site acid alumina with a negative charge ( $\mathrm{SO}^{3-}$ group) of Remazol Yellow FG became more powerful, it may increase the adsorption Remazol Yellow FG.

\section{CONCLUSION}

The difference of active sites each adsorbent, causing differences in adsorption Remazol Yellow FG, where the alumina has a high adsorption capability. Adsorption using alumina and silica acid activation, optimum at low $\mathrm{pH}$ ( $\mathrm{pH} 3$ and $\mathrm{pH}$ 7), whereas activation of base alumina and silica optimum at low $\mathrm{pH}$ and high $\mathrm{pH}(\mathrm{pH} \mathrm{4,} \mathrm{pH} 6$ and $\mathrm{pH} 10)$. The photoanode $\mathrm{Ti} / \mathrm{TiO}_{2}-\mathrm{PbO}$ can be used for photoelectrocatalytic degradation of Remazol Yellow FG, about $72.75 \%$ at $\mathrm{pH}$ 3. The combination of adsorption and photoelectrocatalytic degradation system effective for decolorization of Remazol Yellow FG, about $99.70 \%$.

\section{ACKNOWLEDGEMENT}

The researchers wish to express their gratitude to the Intensif Riset Stranas, Kemenristek dikti of Indonesia, for supporting this research and to the Integrated Mathematics and Natural Science Laboratory of Sebelas Maret University for supporting and providing the facilities for this research.

\section{REFERENCES}

Cervantes, T. N. M., Zaia, D. A. M., Moore, G. J., \& Santana, H. (2012). Photoelectrocatalysis study of the decolorization of synthetic azo dye mixtures on $\mathrm{Ti} / \mathrm{TiO}_{2}$. Electrocatalysis, 4 , 85-91.

Fujishima, A., Zhang, X., \& Tryk, D. A. (2008). $\mathrm{TiO}_{2}$ photocatalysis and related surface phenomena. Surface Science Reports, 63, 515-582.

Gao, H., Zhao, S., Cheng, X., Wang, X., \& Zheng, L. (2013). Removal of anionic azo dyes from aqueous solution using magnetic polymer multi-wall carbon nanotube nanocomposite as adsorbent. Chemical Engineering Journal, 223, 8490.

Gawade, A. S., Vanjara, A. K., \& Sawant M. R. (2005). Removal of disperse dyes from water using surfactant treated alumina. Journal of Chinese Chemica Society, 52, 907-913.

Grimes, C.A., Varghese, O.K., \& Ranjan, S. (2008) Light water hydrogen: The solar generation of hydrogen by water photoelectrolysis. Springer, New York.

Gupta, V. K., Kumar, R., Nayak, A., Saleh, T.A., \& Barakart, M. A. (2013). Adsorptive removal of dyes from aqueous solution onto carbon nanotubes: 
A review. Advances in Colloid and Interface Science, 193-194, 24-34.

Henderson, M.A. (2011). A surface science perspective on $\mathrm{TiO}_{2}$ photocatalysis. Surface Science Reports, 66, 185-297.

He, C., Xiong, Y., Zha, C., Wang, X., Zhu, X. (2003). Approach to Pulse Photoelectrocatalytic Prosess for the Degradation of Organic Pollutants. Journal of Chemical Technology and Biotechnology, 78, 717-723.

Iwaszuk, A., \& Nolan, M. (2013). Lead oxidemodified $\mathrm{TiO}_{2}$ photocatalyst: tuning light absorption and charge carrier separation by lead oxidation state. Catalysis of Science Technology, 3, 2000-2008.

Kannan, C., Sundaram, T., \& Palvannan, T. (2008). Environmentally stable adsorben of tetrahedral silica and non-tetrahedral alumina for removal and recovery of malachite green dye from aqueous solution. Journal of Hazardous Materials, 157, 137-145.

Leelavathi, A., Mukherjee, B., Nethravathi, Kundu, Subhajit, Dhivya, M., Ravishankar, N., \& Madras, G. (2013). Highly photoactive heterostructures of $\mathrm{PbO}$ quantum dots on $\mathrm{TiO}_{2}$. RSC Advances, 3, 20970-20977.

Mahmoud, M. E., Osman, M. M., Hafez, O. F., Hegazi, A., \& Elmelegy, E. (2010). Removal and preconcentration of lead (II) and other heavy metals from water by alumina adsorbents developed by surface-adsorbed-dithizone.

Desalination, 251, 123-130.

Mahmoud, M.E. (2005). Study of the selectivity characteristics incorporated into physically adsorbed alumina phases II mercaptonicotinic acid and potential applications as selective stationary phases for separation, exttraction, and preconcentration of lead (II) and copper (II). Journal of Liquid Chromatography \& Related Technologies, 25(8), 11871199.
Malakootian, M., Masoorian, H. J., Hosseini, A., \& Khanjani, N. (2015). Evaluating the efficacy of alumina/carbon nanotube hybrid adsorbents in removing Azo Reactive Red 198 and Blue 19 dyes from aqueous solutions. Process Safety and Environmental Protection, 96, 125-137.

Ni, M., Leung, M. K. H., Leung, D.Y.C., \& Sumathy, K. (2011). A review and recent developments in photocatalytic water-splitting using $\mathrm{TiO}_{2}$ for hydrogen production. Renewable and Sustainable Energy Reviews, 11, 401-425.

Rehman, S., Ullah, R., Butt, A.M., \& Gohar, N.D. (2009). Strategies of making $\mathrm{TiO}_{2}$ and $\mathrm{ZnO}$ visible light active. Journal of Hazardous Materials, 170, 560-569.

Wahyuningsih, S., Narsito, \& Kartini, I. (2007). Synthesis of anatase-type nanoparticles by slow hydrolysis sol gel process. In International Conference on Chemical Sciences, Yogyakarta, Indonesia, 24-26 May.

Wahyuningsih, S., Purnawan, C., Saraswati, T.E., Pramono, E., Ramelan, A.H., Pramono, S., \& Wisnugroho, A. (2014). Visible light photoelectrocatalytic degradation of rhodamine $\mathrm{B}$ using $\mathrm{Ti} / \mathrm{TiO}_{2}-\mathrm{NiO}$ photoanode. Journal of Environmental Protection, 5, 16301640.

Yola, M.L., Eren, T., Atar, N., \& Wang, S. (2014). Adsorptive and photocatalytic removal of reactive dyes by silver nanoparticle-colemanite ore waste. Chemical Engineering Journal, 242, 333-340. 